\title{
Does Institutional Investor Ownership Influence Corporate Cash Holding?
}

\author{
Yi Jiang ${ }^{1, a, \dagger}$ Hengrui $\mathrm{Li}^{2, b, \dagger}$ Yan $\mathrm{Li}^{3, c, \uparrow}$
}

\author{
${ }^{1}$ Beijing University of Technology \\ ${ }^{2}$ Tianjin University of Commerce \\ ${ }^{3}$ Shandong University of Finance and Economics \\ *Corresponding author.Email: ajiangyi@emails.bjut.edu.cn, ${ }^{b}$ lihengrui@stu.tjcu.edu.cn, \\ c20191724118@mail.sdufe.edu.cn. \\ ${ }^{\dagger}$ These authors contributed equally.
}

\begin{abstract}
Based on a sample of Shenzhen and Shanghai Exchange in 2007-2017, this paper examines the effect of institutional investor ownership on corporate cash holding. We establish the fixed effects model to study the relationship between them, and we use robustness checks and derive our results also have the robustness. Moreover, we do the heterogeneity analysis and find the impact of institutional investor ownership on corporate cash holding is more pronounced in firms with non-state-owned and non-Big 4 auditings. Therefore, the empirical results show that the high institutional ownership improves the level of corporate cash holding and this positive effect is more pronounced in non-state-owned enterprises and firms with low audit quality.
\end{abstract}

Keywords: institutional investor ownership, corporate cash holding

\section{INTRODUCTION}

Cash holding is essential for a corporate. According to Keynes's theory, a firm's cash holdings hedge future cash flow volatility, which is essential for corporates to avoid falling into the financial trap [1]. Moreover, cash holdings can be used in investments to enhance firm competitiveness [2]. Chang and Tang [3] also noted that corporate cash holdings enhance future corporate TFP (Total Factor Productivity). These are all critical for company survival. In this paper, we examine the effect that one of the factors, institutional investors' ownership, may have on corporate cash holding. Numerous studies have investigated the factors that may affect corporate cash holding. S. Ghon Rhee and Huu [4] demonstrate a positive association between economic policy uncertainty and corporate cash holdings from an external perspective. Hou and Liu[5]show a relationship between foreign residency rights and corporate cash holding. A shorter time-to-finance can lead to a reduction in corporate cash holding [6] from an internal perspective. CEOs' beliefs and attitudes toward risky investments contribute to it either according to Chen et al. [7]. Since institutional investors have large cash holdings and a strong ability to analyze information, their investment activities always have a huge impact on the market, so their owners may be significant for the corporates. Considering that there are few scholars examine the effect of institutional investors' ownership on corporate cash holding. This paper examines whether and how institutional investors' ownership affects corporate cash holding to make up for this deficiency.

We know that institutional investors have been the main shareholders in a corporate, especially the IPO corporate. [8] They hold quantities of cash so that they can hold more shares. Exiting research points out many aspects about the effects of institutional investor ownership, like the improvement of the level of corporate governance efficiency[9], corporate sustainability [10], and cost of capital.[11]. Besides, institutional investors holding shares will affect many decision-makings, such as corporate performance, firm value, and CSR. [12] Also, Institutional investors have strong incentives to devote time and resources to monitoring the managerial decisions of firms. [13] As vital decision-making, institutional investors' ownership may influence corporate cash holding decision making since the investors may collect complete information, and their prudence may be higher. Therefore, we predict that high institutional ownership increases corporate cash holding. 
We focus on China's capital markets for two main reasons. First, foreign research on corporate cash holding started relatively early. Their studies of the impact of corporate characteristics, corporate governance, and external environment on cash holding are advanced and comprehensive. However, domestic research on corporate cash holding is confined to corporate governance [14], while the research on the external environment has just started with few results [15]. Therefore, this paper focuses on China's capital market, using the data of domestic listed firms.

Second, the weakness of China's management system provides an ideal platform for us to study the role of institutional investors. Institutional investors have rich experience and strong professional analysis ability. They can effectively participate in corporate governance. However, due to the government's punishment and management of institutional investors is not strong, there will always be various problems. For example, information disclosure involves violations of laws and regulations.

In this paper, we mean to examine the effect of institutional investor ownership on corporate cash holding. Therefore, we conduct a variance inflation factor (VIF) test to control for potential multicollinearity among the variables firstly. The results indicate that no issues of multicollinearity among our variables. Then we perform a baseline regression to examine the impact of institutional investor ownership on corporate cash holding. The results show that highlevel institutional investor ownership increases corporate cash holding. Our conclusion is still valid after performing various robustness checks, alternative measures, and multi-fixed effects model analysis. Finally, we conduct heterogeneity analysis and conclude that the high institutional ownership improves the corporate cash holding. This positive effect is more pronounced in non-SOEs and in firms with low audit quality.

In the existing research, we have studied the impact of many aspects on corporate cash holdings, including the liquidity of stocks, time frictions in capital markets[6], and foreign residence rights[5]. Still, few people have studied the impact of institutional investor ownership on corporate cash holdings. We have expanded our research in this area and made some contributions. Similarly, in the aspect of institutional investors' shareholding, in the existing literature, we have studied the multiple effects of institutional investors on enterprise operation, such as operating performance in IPO firms [8] and investment efficiency. Still, few people have studied the impact of institutional investor ownership on corporate cash holdings. In this regard, we have supplemented some literature.

The remainder of this paper is organized as follows. Section 2 reviews the literature and develops the hypotheses. Section 3 describes the research design. Section 4 presents the empirical results. Finally, Section 5 concludes the paper and provides suggestions.

\section{LITERATURE REVIEW AND HYPOTHESIS DEVELOPMENT}

Cash is a significant part of a Balance sheet for a firm, and it has the strongest liquidity among all assets. Holding a certain amount of cash for a firm may be important. This means that when the firm faces some uncertain situations, like lack of cash flows, bankruptcy, and so on, holding much cash can relieve these crises. Moreover, to a certain degree, holding cash decides the ability to make profits and corporate value. Furthermore, there are also many factors to affect cash holding. Existing research reports a lot of them, such as uncertainty of economic policy, agency problems [16], and the information environment of firms [17].

However, there is little research to study institutional investors' ownership on corporate cash holding. Institutional investors' ownership may influence many aspects of a firm's decision-making, such as corporate governance and capital structure [18] and asset-pricing [19]. Here we focus on one of the - corporate cash holding. We believe that higher institutional investors' ownership may improve the level of corporate governance, and institutional investors could gain information more completely. Hence, their prudence will be higher when they make decisions to increase corporate cash holding. Therefore, we provide the following hypothesis.

H1. High institutional ownership increases corporate cash holding.

Generally, SOEs (state-owned enterprises) receive more social supervision than non-SOEs, normally getting a better reputation [20]. Hence, corporate cash holding of SOEs is higher than which of non-stateowned enterprises since it is easier for them to obtain bank loans. As we know from above, SOEs have larger cash holdings than non-SOEs, which means they have larger radices. Therefore, the change in corporate cash holding caused by institutional investors' ownership is not notable. Hence, we propose our second hypothesis as follows.

$\mathrm{H} 2$. The promoting effect of institutional ownership on corporate cash holding is more pronounced in nonstate-owned enterprises.

Under normal circumstances, firms with stricter external controls have better corporate governance [21]. According to previous studies, we know that institutional investors can optimize the ownership structure, improve management structure, standardize business management and improve operational efficiency by holding more stocks and attending 
congregate litigations [22]. In our case, we speculate that due to the high level of external supervision of firms with high audit quality, institutional investors' impact may become obscure, which means there is an alternative relationship between investor holding and high-quality audits. In the big 4 , with strict external monitoring and high levels of corporate governance, investors can trust and choose to follow management decisions, while in non-big 4 with weak external monitoring, investors tend to improve firm performance by holding stocks. From this point of view, institutional investors may be more actively involved in corporate governance in non-big 4 circumstances. Hence, we propose our third and last hypothesis as follows.

H3. The promoting effect of institutional ownership on corporate cash holding is more pronounced in firms with low audit quality.

\section{RESEARCH DESIGN}

\subsection{Sample and Data}

Our samples are from all A-share listed firms in Shanghai and Shenzhen Stock Exchanges from 2007 to 2017, and financial and accounting data are from the Wind and CSMAR databases. This study excludes financially and ST-listed firms and deletes the firms with missing related research variables. In addition, to eliminate the influence of extreme value on the research results, we winsorize the data by $1 \%$ above and $1 \%$ below. Finally, our sample includes 10,792 firm-year observations.

\subsection{Definitions of Variables}

In this paper, we define the following variables.

\begin{tabular}{|c|c|}
\hline Variables & Definitions \\
\hline $\operatorname{Cash}_{i, t}$ & $\begin{array}{l}\text { Cash holding, the ratio of cash and } \\
\text { equivalents to total assets of firm } i \text { in year } \\
t \text {, and the alternative measure is the ratio } \\
\text { of cash and equivalents to net total assets } \\
\text { of firm } i \text { in year } t \text {. }\end{array}$ \\
\hline$I N S T_{i, t}$ & $\begin{array}{l}\text { Institutional investor ownership, the } \\
\text { shareholding ratio of institutional } \\
\text { investors of firm } i \text { in year } t \text {. }\end{array}$ \\
\hline$S i z e_{i, t}$ & $\begin{array}{l}\text { Firm size, the natural logarithm value of } \\
\text { the book value of total assets of firm } i \text { in } \\
\text { year } t \text {. }\end{array}$ \\
\hline$R O A_{i, t}$ & $\begin{array}{l}\text { Return on assets, calculated as net profit } \\
\text { divided by the book value of total assets } \\
\text { of firm } i \text { in year } t \text {. }\end{array}$ \\
\hline$N W C_{i, t}$ & $\begin{array}{l}\text { The net working capital, calculated as the } \\
\text { current assets minus the current liabilities } \\
\text { divided by the net total assets of firm } i \text { in } \\
\text { year } t \text {. }\end{array}$ \\
\hline$L E V_{i, t}$ & $\begin{array}{l}\text { Firm financial leverage, calculated as the } \\
\text { book value of total debt divided by the } \\
\text { book value of total assets of firm } i \text { in year } \\
t \text {. }\end{array}$ \\
\hline$M B_{i, t}$ & Market-to-book ratio, calculated as the \\
\hline
\end{tabular}

market value of equity divided by the book value of equity of firm $i$ in year $t$.

The listing age, calculated as the natural logarithm of the current year minus the year of listing of firm $i$ in year $t$.

\subsection{Measurement of corporate cash holding}

Corporate cash holding (Cashi,t) is our dependent variable, which refers to the amount of cash held by firms to meet the needs of production and operation. Following Bugshan et al. [23], we choose the ratio of cash and cash equivalent to the firm's total assets as the descriptive variable of the firm's cash holding level. To ensure the robustness of the estimation results, referring to the article of Bugshan et al.[23], we select the ratio of the firm's cash and cash equivalents to the firm's net assets as a substitute index. A firm needs to hold a certain amount of cash, but for firms with poor profitability, holding cash may reduce firms' future earnings.

\subsection{Measurement of institutional ownership}

Institutional ownership (INSTi,t) is our key independent variable. Institutional ownership is calculated as the shareholding ratio of institutional investors of firm $i$ in year $t$. The so-called institutional investors are legal entities that use their own funds or funds raised from the scattered public to invest in securities, including some insurance companies, pension funds, securities companies, and banks. Institutional investors often hold huge disposable funds, have strong professional analysis ability and information collection ability, so they often intervene in corporate governance, which is conducive to improving the management quality of listed companies.

\subsection{Model specification}

To examine the effect of institutional investor ownership on corporate cash holding, we specify the following fixed effects model:

$$
\begin{array}{r}
\text { Cashi, } t=\beta 0+\beta 1 \times I N S T i, t+ \\
\sum_{k} \text { rkcontrolk, } i, t+\sum \text { industry }+\sum \text { year }+ \\
\varepsilon i, t(1)
\end{array}
$$

Where Cashi,t represents the corporate cash holding. The larger the value is, the higher the level of the firm's cash holding.INSTi,t is our core independent variable, representing the shareholding ratio of institutional investors in the firm. The larger the value is, the higher the shareholding ratio is. Following Bugshan et al.[23] and Chen et al. [24], we control the influencing factors of corporate cash holdings, including firm size(Sizei, $t$ ), return on assets (ROAi,t), the networking capital $(\mathrm{NWCi}, \mathrm{t})$, firm financial leverage $(\mathrm{LEVi}, \mathrm{t})$, market-to- 
book ratio $(\mathrm{MBi}, \mathrm{t})$, and the listing age (Agei,t). Please refer to the appendix for details of these variables.

\section{EMPIRICAL RESULTS}

\subsection{Descriptive Statistics}

We draw some useful information from Table 1, which shows descriptive statistics of related variables. Apparently, the average of Cashi,t is 0.181 , and its standard deviation is 0.137 . The mean of Sizei,t is 22.050 , and the average LEVi,t is 0.373 , meaning that the average proportion of debt in the firm's total assets is $37.3 \%$, that is to say, $62.7 \%$ is another equity.

Additionally, a variance inflation factor (VIF) test is conducted to control for potential multicollinearity among the variables, and the results are shown in Table 2. We see that all the VIFs of all the explanatory variables are smaller than 10 , indicating no multicollinearity issues among our variables.

Table 1. Descriptive statistics

\begin{tabular}{|c|c|c|c|c|c|c|}
\hline $\begin{array}{l}\text { Variable } \\
s\end{array}$ & $N$ & Mean & $\begin{array}{l}\text { Std. } \\
\text { dev. }\end{array}$ & 25 th & $\begin{array}{l}\text { Media } \\
n\end{array}$ & $75 \mathrm{th}$ \\
\hline Cashi,t & $\begin{array}{l}1079 \\
2\end{array}$ & 0.181 & $\begin{array}{l}0.13 \\
7\end{array}$ & 0.082 & 0.140 & 0.238 \\
\hline INSTi,t & $\begin{array}{l}1079 \\
2\end{array}$ & 0.359 & $\begin{array}{l}0.22 \\
8\end{array}$ & 0.157 & 0.344 & 0.539 \\
\hline Sizei,t & $\begin{array}{l}1079 \\
2\end{array}$ & $\begin{array}{l}22.05 \\
0\end{array}$ & $\begin{array}{l}1.26 \\
6\end{array}$ & $\begin{array}{l}21.15 \\
5\end{array}$ & 21.823 & $\begin{array}{l}22.68 \\
0\end{array}$ \\
\hline$R O A i, t$ & $\begin{array}{l}1079 \\
2\end{array}$ & 0.051 & $\begin{array}{l}0.04 \\
8\end{array}$ & 0.021 & 0.045 & 0.074 \\
\hline$N W C i, t$ & $\begin{array}{l}1079 \\
2\end{array}$ & 0.256 & $\begin{array}{l}0.24 \\
4\end{array}$ & 0.085 & 0.250 & 0.429 \\
\hline$L E V i, t$ & $\begin{array}{l}1079 \\
2\end{array}$ & 0.373 & $\begin{array}{l}0.19 \\
7\end{array}$ & 0.214 & 0.360 & 0.517 \\
\hline$M B i, t$ & $\begin{array}{l}1079 \\
2\end{array}$ & 2.502 & $\begin{array}{l}1.89 \\
3\end{array}$ & 1.189 & 1.998 & 3.251 \\
\hline Agei,t & $\begin{array}{l}1079 \\
2 \\
\end{array}$ & 1.750 & $\begin{array}{l}0.61 \\
6\end{array}$ & 1.386 & 1.792 & 2.197 \\
\hline
\end{tabular}

This table reports the descriptive statistics of our variables. The sample includes 10792 firm-year observations listed on the Shenzhen and Shanghai Stock Exchange from 2007 to 2017. We estimate the mean, standard deviation, 25th quantile, median and 75 th quantile for each variable.

Table 2. VIF tests of key variables

\begin{tabular}{lll}
\hline & VIF & 1/VIF \\
\hline$I N S T_{i, t}$ & 1.361 & 0.735 \\
Size $_{i, t}$ & 1.745 & 0.573 \\
ROA $_{i, t}$ & 1.323 & 0.756 \\
$N W C_{i, t}$ & 1.923 & 0.520 \\
$L E V_{i, t}$ & 2.141 & 0.467 \\
$M B_{i, t}$ & 1.447 & 0.691 \\
Age $_{i, t}$ & 1.397 & 0.716 \\
Mean & VIF & 1.620 \\
\hline
\end{tabular}

This table reports the VIF test results. The sample includes 10792 firm - year observations listed on the
Shenzhen and Shanghai Stock Exchange from 2007 to 2017.

\subsection{The Effect of $A$ on $B$}

Table 3 reports the results of our baseline regression. Column (1) reports the results of ordinary least squares (OLS) recession and column (2) shows industry-year fixed effects recession results. Obviously, the coefficient of INSTi,t is 0.031 in column (1), and it is significant at the $1 \%$ level, indicating that the institutional shareholders' ownership has a positive, improving effect on the corporate cash holding. This result supports our $\mathrm{H1}$, which considers that high institutional ownership increases corporate cash holding. In addition, the results for the control variables are largely consistent with the literature. For instance, firm size[24] and the net working capital to assets[24] are positively associated with listed firms' CSR performance.

Table 3. The influence of institutional investor ownership on corporate cash holding

\begin{tabular}{|c|c|c|}
\hline \multirow[t]{2}{*}{ Dependent variable $=$} & \multicolumn{2}{|c|}{$\operatorname{Cash}_{i, t}$} \\
\hline & (1) & (2) \\
\hline \multirow[t]{2}{*}{$I N S T_{i, t}$} & $0.031 * * *$ & $0.025 * * *$ \\
\hline & $(6.20)$ & $(4.97)$ \\
\hline \multirow[t]{2}{*}{ Size $_{i, t}$} & $0.008 * * *$ & $0.010 * * *$ \\
\hline & $(5.16)$ & $(6.71)$ \\
\hline \multirow[t]{2}{*}{$R O A_{i, t}$} & -0.002 & -0.001 \\
\hline & $(-0.08)$ & $(-0.04)$ \\
\hline \multirow[t]{2}{*}{$N W C_{i, t}$} & $0.410 * * *$ & $0.422 * * *$ \\
\hline & $(64.59)$ & $(63.95)$ \\
\hline \multirow[t]{2}{*}{$L E V_{i, t}$} & $0.035^{* * *}$ & $0.044 * * *$ \\
\hline & $(4.43)$ & $(5.60)$ \\
\hline \multirow[t]{2}{*}{$M B_{i, t}$} & $-0.002 * * *$ & $-0.003 * * *$ \\
\hline & $(-3.20)$ & $(-3.93)$ \\
\hline \multirow[t]{2}{*}{$A g e_{i, t}$} & $-0.061 * * *$ & $-0.038 * * *$ \\
\hline & $(-28.68)$ & $(-14.15)$ \\
\hline \multirow[t]{2}{*}{ Constant } & -0.015 & $-0.091 * *$ \\
\hline & $(-0.51)$ & $(-2.52)$ \\
\hline Year & No & Yes \\
\hline Industry & No & Yes \\
\hline Observations & 10792 & 10792 \\
\hline Adjusted $\mathrm{R}^{2}$ & 0.500 & 0.502 \\
\hline
\end{tabular}

This table reports the influence of institutional investors' ownership on corporate cash holding of firms listed on the Shenzhen and Shanghai Stock Exchange. The OLS regression results are reported in column (1). Results for the industry-year fixed effects model are reported in column (2). The variable Cashi,t measures firms' cash holding, the ratio of cash and equivalents to total assets of firm i in year $t$. The other variables are defined in Appendix, and t-statistics are reported in parentheses. The superscripts $*, * *$, and $* * *$ indicate 
significance at the $10 \%, 5 \%$, and $1 \%$ confidence levels, respectively.

\subsection{Robustness checks}

\subsubsection{Alternative measures}

From our baseline recession analysis above, the definition of corporate cash holding we used is the cash and its equivalent of a firm divided by its total assets. However, a large amount of cash flow can be gained by debts. Therefore, following Bugshan[23], we replace total assets with net assets, that is, cash and equivalents to total net assets, to test the robustness of our results.

Table 4 reports the results of the changing indicators, in column (1), the effect of institutional investors ownership on cash holding, that is the coefficient of INSTi,t is 0.044 , which is also statistically significant at the $1 \%$ level, indicating its positive effect on cash holding. Hence, our conclusion is relatively stable and reliable.

Table 4. Robustness checks: Alternative measure

\begin{tabular}{|c|c|c|}
\hline \multirow[t]{2}{*}{ Dependent variable $=$} & \multicolumn{2}{|c|}{ Cash $_{i, t}$} \\
\hline & (1) & (2) \\
\hline \multirow[t]{2}{*}{$I N S T_{i, t}$} & $0.044 * * *$ & $0.037 * * *$ \\
\hline & $(5.29)$ & $(4.47)$ \\
\hline \multirow[t]{2}{*}{$S i z e_{i, t}$} & $0.023 * * *$ & $0.030 * * *$ \\
\hline & $(9.43)$ & $(11.75)$ \\
\hline \multirow[t]{2}{*}{$R O A_{i, t}$} & 0.049 & 0.032 \\
\hline & $(1.40)$ & $(0.91)$ \\
\hline \multirow[t]{2}{*}{$N W C_{i, t}$} & $0.510 * * *$ & $0.531 * * *$ \\
\hline & $(47.90)$ & $(48.20)$ \\
\hline \multirow[t]{2}{*}{$L E V_{i, t}$} & $0.359 * * *$ & $0.361 * * *$ \\
\hline & $(27.36)$ & $(27.61)$ \\
\hline \multirow[t]{2}{*}{$M B_{i, t}$} & $-0.003 * * *$ & -0.002 \\
\hline & $(-3.23)$ & $(-1.55)$ \\
\hline \multirow[t]{2}{*}{$A g e_{i, t}$} & $-0.093 * * *$ & $-0.043 * * *$ \\
\hline & $(-26.26)$ & $(-9.76)$ \\
\hline \multirow[t]{2}{*}{ Constant } & $-0.328 * * *$ & $-0.502 * * *$ \\
\hline & $(-6.65)$ & $(-8.63)$ \\
\hline Year & No & Yes \\
\hline Industry & No & Yes \\
\hline Observations & 10792 & 10792 \\
\hline Adjusted $\mathrm{R}^{2}$ & 0.300 & 0.307 \\
\hline
\end{tabular}

This table reports the influence of institutional investors' ownership on the cash holding of firms listed on the Shenzhen and Shanghai Stock Exchange. The OLS regression results are reported in column (1), and the results of the industry-year fixed effects model are reported in column (2). Here we chose the alternative measure: the ratio of cash and equivalents to net total assets of firm $i$ in year $t$. The other variables are defined in Appendix, and t-statistics are reported in parentheses. The superscripts $*, * *$, and $* * *$ indicate significance at the $10 \%, 5 \%$, and $1 \%$ confidence levels, respectively.

\subsubsection{Multi-fixed effects model analysis}

Table 5. Robustness checks: Multi-fixed effects model analysis

\begin{tabular}{|c|c|c|c|c|}
\hline \multirow{2}{*}{$\begin{array}{l}\text { Dependent } \\
\text { variable= }\end{array}$} & \multicolumn{4}{|c|}{ Cash $_{i, t}$} \\
\hline & $(1)$ & $(2)$ & (3) & (4) \\
\hline \multirow{3}{*}{$I N S T_{i, t}$} & $0.024 * *$ & $0.022 * *$ & $0.024 * *$ & $0.022 * *$ \\
\hline & $*$ & $*$ & $*$ & $*$ \\
\hline & $(4.51)$ & $(3.93)$ & $(4.41)$ & $(3.93)$ \\
\hline \multirow{3}{*}{ Size $_{i, t}$} & $0.014 * *$ & $0.014 * *$ & $0.014 * *$ & $0.014 * *$ \\
\hline & $*$ & $*$ & $*$ & \\
\hline & $(6.50)$ & $(6.54)$ & $(6.37)$ & $(6.32)$ \\
\hline \multirow[t]{2}{*}{$R O A_{i, t}$} & -0.033 & $-0.037^{*}$ & $-0.037 *$ & $-0.042 *$ \\
\hline & $(-1.55)$ & $(-1.70)$ & $(-1.69)$ & $(-1.87)$ \\
\hline \multirow{3}{*}{$N W C_{i, t}$} & $0.426^{* *}$ & $0.426^{* *}$ & $0.428 * *$ & $0.427 * *$ \\
\hline & & & & \\
\hline & $(57.98)$ & $(56.84)$ & $(57.24)$ & $(56.10)$ \\
\hline \multirow{4}{*}{$L E V_{i, t}$} & $0.054 * *$ & $0.053 * *$ & $0.059 * *$ & $0.059^{* *}$ \\
\hline & & & $*$ & \\
\hline & $(6.45)$ & $(6.19)$ & $(6.94)$ & $(6.72)$ \\
\hline & - & - & - & - \\
\hline \multirow[t]{4}{*}{$M B_{i, t}$} & $0.003 * *$ & $0.003 * *$ & $0.003 * *$ & $0.003 * *$ \\
\hline & & & & \\
\hline & $(-3.65)$ & $(-3.45)$ & $(-3.44)$ & $(-3.36)$ \\
\hline & - & - & - & - \\
\hline \multirow[t]{3}{*}{$A g e_{i, t}$} & $0.097 * *$ & $0.092 * *$ & $0.093 * *$ & $0.088 * *$ \\
\hline & $\begin{array}{l}* \\
(-22.32)\end{array}$ & $\begin{array}{l}* \\
(-20.48)\end{array}$ & $\begin{array}{l}* \\
(-20.59)\end{array}$ & $\begin{array}{l}* \\
(-19.00)\end{array}$ \\
\hline & - & $-0.087 *$ & $-0.084 *$ & $-0.094 *$ \\
\hline \multirow[t]{2}{*}{ Constant } & $\begin{array}{l}0.119 * * \\
*\end{array}$ & & & \\
\hline & $(-2.65)$ & $(-1.75)$ & $(-1.70)$ & $(-1.86)$ \\
\hline Year & Yes & No & No & No \\
\hline Firm & Yes & Yes & Yes & Yes \\
\hline $\begin{array}{l}\text { Industry*Ye } \\
\text { ar }\end{array}$ & No & Yes & No & Yes \\
\hline $\begin{array}{l}\text { Province*Ye } \\
\text { ar }\end{array}$ & No & No & Yes & Yes \\
\hline Observations & 10792 & 10792 & 10792 & 10792 \\
\hline Adjusted R2 & 0.513 & 0.522 & 0.533 & 0.542 \\
\hline
\end{tabular}

This table reports the results of analyzing a model with multiple fixed effects. Column (1) reports the results of firm and year fixed effects, column (2) reports the results of firm fixed effects with industry-year interactions, column (3) reports the results of firm fixed effects with province-year interactions, and column (4) reports the results of firm fixed effects with both above interactions. The variable Cashi,t measures the corporate cash holding, which is calculated as the Cash scores published by WIND and CSMAR database. The other variables are defined in Appendix, and t-statistics are reported in parentheses. The superscripts *,**, and *** indicate significance at the $10 \%, 5 \%$, and $1 \%$ confidence levels, respectively.

Considering that other unobservable factors may have potential impacts on a firm's cash holdings and influence the results, we conduct robustness tests to eliminate the impacts. During the test, we follow Liu [25] 
and introduce multiple fixed effects. The first column of Table 5 reports the results of firm and year fixed effects. The second column reports the results of firm fixed effects with industry-year interaction. The third column reports the results of firm fixed effects with provinceyear interaction, and the fourth column reports the results of firm fixed effects with both above interactions. From Table 5, we conclude that the coefficients of INSTi,t are all statistically significant and positive in all four columns. It proves that the conclusions obtained in our baseline regression are still holding when excluding the influence of year, firm, industry, and province factors.

\subsection{Heterogeneity analysis}

In this section, we examine whether the positive correlation between institutional ownership and corporate cash holding depends on the company's characteristics and external monitoring. We use property rights and audit quality as standards.

\subsubsection{Property rights}

Table 6. Heterogeneity analysis: Property rights

\begin{tabular}{|c|c|c|}
\hline \multirow[t]{2}{*}{ Dependent variable $=$} & \multicolumn{2}{|c|}{ Cash $_{i, t}$} \\
\hline & SOEs & Non-SOES \\
\hline \multirow[t]{2}{*}{$I N S T_{i, t}$} & 0.007 & $0.016^{* *}$ \\
\hline & $(0.89)$ & $(2.43)$ \\
\hline \multirow[t]{2}{*}{ Size $_{i, t}$} & $0.006 * * *$ & $0.014 * * *$ \\
\hline & $(3.04)$ & $(6.12)$ \\
\hline \multirow[t]{2}{*}{$R O A_{i, t}$} & 0.016 & 0.002 \\
\hline & $(0.52)$ & $(0.08)$ \\
\hline \multirow[t]{2}{*}{$N W C_{i, t}$} & $0.376^{* * *}$ & $0.424 * * *$ \\
\hline & $(36.61)$ & $(49.85)$ \\
\hline \multirow[t]{2}{*}{$L E V_{i, t}$} & $0.042 * * *$ & $0.038 * * *$ \\
\hline & $(4.08)$ & $(3.54)$ \\
\hline \multirow[t]{2}{*}{$M B_{i, t}$} & -0.000 & $-0.002 *$ \\
\hline & $(-0.04)$ & $(-1.79)$ \\
\hline \multirow[t]{2}{*}{$A g e_{i, t}$} & $-0.035^{* * *}$ & $-0.035^{* * *}$ \\
\hline & $(-7.90)$ & $(-10.05)$ \\
\hline \multirow[t]{2}{*}{ Constant } & -0.003 & $-0.150 * * *$ \\
\hline & $(-0.07)$ & $(-3.02)$ \\
\hline Year & Yes & Yes \\
\hline Industry & Yes & Yes \\
\hline Observations & 3465 & 7327 \\
\hline Adjusted $\mathrm{R}^{2}$ & 0.377 & 0.536 \\
\hline
\end{tabular}

This table reports the heterogeneity analysis on Property Rights. Columns (1) and (2) report the subsample analysis on Property Rights. Industry-year fixed effects are included in analyses. The variable Cashi,t measures the corporate cash holding, which is calculated as the Cash scores published by WIND and CSMAR database. The other variables are defined in Appendix, and $\mathrm{t}-$ statistics are reported in parentheses.
The superscripts $*, * *$, and $* * *$ indicate significance at the $10 \%, 5 \%$, and $1 \%$ confidence levels, respectively.

To investigate the heterogeneity analysis of property rights, we first divide all samples into two groups according to the classification of SOEs (state-owned enterprises) and non-SOEs (non-state-owned enterprises). Then reconduct baseline regressions within two subsamples respectively. We see from Table 6 that the coefficients of INSTi,t in two columns are both positive. The result in column (1) reports nonsignificant, and the result in column (2) is significant at the $5 \%$ level, indicating that the positive impacts of institutional investors ownership on corporate cash holding are more pronounced in non-SOEs. The results support H2.

\subsubsection{Audit quality}

Table 7. Heterogeneity analysis: Audit quality

\begin{tabular}{lll}
\hline Dependent variable $=$ & \multicolumn{2}{c}{ Cash $_{i, t}$} \\
\cline { 2 - 3 } & Big4 & Non-Big4 \\
\hline$I N S T_{i, t}$ & 0.005 & $0.025^{* * *}$ \\
& $(0.40)$ & $(4.66)$ \\
Size $_{i, t}$ & 0.000 & $0.012^{* * *}$ \\
& $(0.08)$ & $(7.04)$ \\
$R O A_{i, t}$ & -0.053 & 0.000 \\
& $(-0.89)$ & $(0.01)$ \\
$N W C_{i, t}$ & $0.310^{* * *}$ & $0.421^{* * *}$ \\
& $(14.27)$ & $(60.96)$ \\
$L E V_{i, t}$ & -0.001 & $0.042^{* * *}$ \\
& $(-0.06)$ & $(5.07)$ \\
$M B_{i, t}$ & $0.010^{* * *}$ & $-0.003^{* * *}$ \\
Age $e_{i, t}$ & $(3.58)$ & $(-4.05)$ \\
& -0.009 & $-0.039^{* * *}$ \\
Constant & $(-1.13)$ & $(-13.88)$ \\
& 0.110 & $-0.127^{* * *}$ \\
Year & $(0.87)$ & $(-3.22)$ \\
Industry & Yes & Yes \\
Observations & Yes & Yes \\
Adjusted $\mathrm{R}^{2}$ & 732 & 10060 \\
\hline This table & 0.374 & 0.509 \\
\hline
\end{tabular}

This table reports the heterogeneity analysis on Audit quality. Columns (1) and (2) report the subsample analysis on Audit quality. Industry-year fixed effects are included in analyses. The variable Cashi,t measures the corporate cash holding, which is calculated as the Cash scores published by WIND and CSMAR database. The other variables are defined in Appendix, and $\mathrm{t}-$ statistics are reported in parentheses. The superscripts *,**, and $* * *$ indicate significance at the $10 \%, 5 \%$, and $1 \%$ confidence levels, respectively.

To further study whether the impact of institutional investors' ownership on corporate cash holding is affected by audit quality, we construct another two sets of subsamples based on the firms of accountants. 
Specifically, whether the analyst who audits the firm's financial status is employed by the four major international accounting firms, from Table 7, we can observe that the coefficients of INSTi,t is positive and significant at $1 \%$ level in column (2) but nonsignificant in column (1). The results suggest that when the analyst is from non-Big 4, the institutional investors' ownership may have more significant positive impacts on corporate cash holdings. According to results above, we conclude that institutional investors' shareholdings can replace the supervision roles of other external factors, such as a higher-quality audit environment, which means institutional investors play a more significant role in firms with weaker oversight environments. These results support $\mathrm{H} 3$.

\section{CONCLUSION}

Based on the sample data of firms from 2007 to 2017, we study the impacts of institutional investor ownership on corporate cash holding. The empirical results show that institutional investors have a positive correlation with corporate cash holdings. Furthermore, we use the multiple fixed effects model to check the robustness of the model, including the influence of firm size(Sizei,t), return on assets (ROAi,t), the networking capital $(\mathrm{NWCi}, \mathrm{t})$, firm financial leverage (LEVi,t), market-tobook ratio $(\mathrm{MBi}, \mathrm{t})$, and the listing age (Agei,t) on corporate cash holding. After the check, the conclusion of the paper is still robust. We find that the positive effect of institutional investor ownership on corporate cash holding was more significant in non-state-owned and non-big 4 auditings through heterogeneity analysis.

In this regard, we put forward the following suggestions. First, we suggest that the government strengthen institutional investors' supervision and formulate relevant laws and regulations. Second, it is suggested that non-state-owned enterprises and companies with low audit ability should further strengthen the monitoring of institutional investors and improve the enterprise management system.

\section{REFERENCES}

[1] Oguz Ersan, Ender Demir, Economic policy uncertainty and cash holdings: Evidence from BRIC countries, in: Emerging Markets Review, December 2017, pp. 189-200. DOI: https://doi.org/10.1016/j.ememar.2017.08.001

[2] Xingquan Yang, Liang Han, Wanli Li, Xingqiang Yin, Lin Tian, Monetary policy, cash holding and corporate investment: Evidence from China, in: China Economic Review, December 2017, pp. 110122.

DOI: https://doi.org/10.1016/j.chieco.2017.09.001

[3] Chong-Chuo Chang, Hui-Wen Tang, Corporate cash holdings and total factor productivity - A global analysis, in: The North American Journal of Economics and Finance, January 2021, 101316. DOI: https://doi.org/10.1016/j.najef.2020.101316

[4] Huu Nhan Duong, Justin Hung Nguyen, My Nguyen, S. Ghon Rhee, Navigating through economic policy uncertainty: The role of corporate cash holdings, in: Journal of Corporate Finance, June 2020, $101607 . \quad$ DOI: https://doi.org/10.1016/j.jcorpfin.2020.101607

[5] Canran Hou, Huan Liu, Foreign residency rights and corporate cash holdings, in: Journal of Corporate Finance, October 2020, 101702. DOI: https://doi.org/10.1016/j.jcorpfin.2020.101702

[6] Mark Raun Moritzen, Alexander Schandlbauer, The impact of competition and time-to-finance on corporate cash holdings, in: Journal of Corporate Finance, December 2020, 101502. DOI: https://doi.org/10.1016/j.jcorpfin.2019.101502

[7] Yenn-Ru Chen, Keng-Yu Ho, Chia-Wei Yeh, CEO overconfidence and corporate cash holdings, in: Journal of Corporate Finance, June 2020,101577. DOI:

https://doi.org/10.1016/j.jcorpfin.2020.101577

[8] Chui Zi Ong, Rasidah Mohd-Rashid, Kamarun Nisham Taufil-Mohd, Do institutional investors drive the IPO valuation? Borsa Istanbul Review, vol.20, 2020, pp.307-321.DOI https://doi.org/10.1016/j.bir.2020.05.003.

[9] Liu Deng.An empirical analysis of the shareholding ratio of institutional investors, the level of corporate governance and corporate performance. Economic Research Guide, vol.04, 2021, pp.47-49.

[10] Shin, Ilhang and Park, Sorah. Role of Foreign and Domestic Institutional Investors in Corporate Sustainability: Focusing on R\&amp;D Investment. Sustainabilit, $\quad$ vol. $12, \quad 2020$, https://www.mdpi.com/2071-1050/12/20/8754

[11] AlHares, A. , Dominic, G. and Abu-Asi, T. Institutional Ownership and Cost of Capital: An International Study. Theoretical Economics Letters, vol.10, 2020, pp.1031-1043. doi: 10.4236/tel.2020.105060.

[12] Singh Shaili; Khare Arpita; Pandey Shivendra Kumar; Sharma Dheeraj P. Industry and community peers as drivers of corporate social responsibility in India: The contingent role of institutional investors. Journal of Cleaner Production, vol.295, 2021, pp.126316. DOI: https://doi.org/10.1016/j.jclepro.2021.126316. 
[13] Adrian (Wai Kong) Cheung, Mostafa Monzur Hasan, Joye Khoo.Distracted institutional shareholders and corporate cash holdings, International Review of Economics \& Finance, vol.71, 2021, pp.453-466. DOI: https://doi.org/10.1016/j.iref.2020.08.018.

[14] Naikang Gu, Xiaoyong Wan, Hui Chen, Macroeconomic conditions, financing constraints and the level of cash holdings, in: Journal of Economics, 2010 (04), pp. 33-53.

[15] Weiqiu Yuan, Chengyong Yu, Fangfang Zou, Summary of Research on the Influencing Factors of Corporate Cash Holdings, in: Journal of Economics, 2013 (01), pp. 134-138.

[16] Liu Chang, Zhao Rui. Centralization of decisionmaking power allocation and cash holding. Journal of Beijing business and Technology University (SOCIAL SCIENCE EDITION), vol.36,2021, pp.64-79, doi: 10 . $12085 / j$. issn. 10096116. 2021. 02.006

[17] Peter Clarkson, Ru Gao, Kathleen Herbohn, The relationship between a firm's information environment and its cash holding decision, Journal of Contemporary Accounting \& Economics, vol.16, 2020, pp.100201. DOI: https://doi.org/10.1016/j.jcae.2020.100201.

[18] Choi PMS, Choi JH, Chung CY, An YJ. Corporate Governance and Capital Structure: Evidence from Sustainable Institutional Ownership. Sustainability, vol.12, 2020, pp.4190. DOI: https://doi.org/10.3390/su12104190

[19] Ecenur Uğurlu-Yıldırım, İlkay Şendeniz-Yüncü, Additional factor in asset-pricing: Institutional ownership, Finance Research Letters, vol. 40,2021, pp.101697.

DOI: https://doi.org/10.1016/j.frl.2020.101697.

[20] Loren Brandt, Hongbin Li, Bank discrimination in transition economies: ideology, information, or incentives, in: Journal of Comparative Economics, 2003, pp. 387-413. DOI: https://doi.org/10.1016/S0147-5967(03)00080-5

[21] Meng, X.H., Zeng, S.X., Tam, C.M., From voluntarism to regulation: a study on ownership, economic performance, and corporate environmental information disclosure in China, in: Journal of Business Ethics 116 (1), 2013, pp. 217 232.

[22] Thomas J. Chemmanur, Gang Hu, K.C. John Wei, The role of institutional investors in corporate and entrepreneurial finance, in: Journal of Corporate Finance, February 2021, 101833. DOI:

\section{https://doi.org/10.1016/j.jcorpfin.2020.101833}

[23] Abdullah Bugshan, Faisal Alnori, Walid Bakry, 2021,Shariah compliance and corporate cash holdings,in:Research in International Business and Finance, $\quad 56 \quad$ (2021) 101383. DOI:https://doi.org/10.1016/j.ribaf.2021.101383

[24] Yumei Feng, Yuying Pan, Lu Wang, Ahmet Sensoy, 2021,The voice of minority shareholders: Online voting and corporate social responsibility.,in:Research in International Business and Finance, $57 \quad$ (2021) 101408.DOI:https://doi.org/10.1016/j.ribaf.2021.1 01408

[25] Liu, X., Corruption culture and corporate misconduct, in: Journal of Economics 122 (2), 2016, pp. 307-327. 